\title{
SÍNTESIS CURRICULARES
}

\section{SILVANA RABINOVICH}

Doctora en Filosofía, investigadora en el Seminario de Hermenéutica del Instituto de Investigaciones Filológicas de la UNAM, tutora en el Posgrado en Filosofía de la Facultad de Filosofía y Letras de la UNAM, es responsable del Proyecto PAPIIT IN402317 "Heteronomías de la justicia: nomadismo y hospitalidad en el lenguaje". Ha publicado, entre otros: La Biblia y el drone: sobre usos y abusos de figuras bíblicas en el discurso político de Israel (2013), Heteronomías de la lectura (2013). Actualmente se encuentran en prensa: Retornos del Discurso del "Indio" (para Mahmud Darwish) (ed.) y Heteronomías de la justicia: de exilios y utopías (co-ed.).

\section{RODRIGO KARMY}

Doctor en Filosofía, profesor e investigador del Centro de Estudios Árabes de la Universidad de Chile. Sus libros son: Escritos Bárbaros (2014). Ensayos sobre Razón Imperial y mundo árabe contemporáneo (2016) y Políticas de la ex-carnación. Para una genealogía teológica de la biopolítica. Además, ha editado: Biopolíticas, gobierno y salud pública. Miradas para un diagnóstico diferencial (2014) y Políticas de la interrupción. Ensayos sobre Giorgio Agamben (2011).

\section{FRANCESCA GARGALlO CELENTANI}

Novelista, poeta y ensayista que ha publicado 24 libros, entre ellos: $A l$ paso de los días (novela), La decisión del capitán (novela), Verano con 
lluvia (cuentos), Feminismos desde Abya Yala (filosofía), Ideas feministas latinoamericanas (historia de las Ideas), Garifuna, Garinagu, Caribe (historia) y A la lluvia se prepara la tarde (poesía). Licenciada en Filosofía y maestra y doctora en Estudios Latinoamericanos, es miembro fundador de la Sociedad Cultural Nuestra América y de Revista de Políticas de la Filosofía. Pensares y Quehaceres. De 2001 a 2014 fue profesora de tiempo completo en la Universidad Autónoma de la Ciudad de México. Desde 2014 ha vuelto enteramente a la actividad artística y de investigación autónoma. Actualmente coordina la colección "Feminismos Nuestroamericanos" en la editorial bogotana Desde Abajo.

\section{YASNAYA AGUILAR}

Forma parte del Colegio Mixe (COLMIX). Estudió Lengua y Literaturas Hispánicas y cursó la maestría en Linguística en la UNAM. Ha colaborado en diversos proyectos sobre divulgación de la diversidad linguística, desarrollo de contenidos gramaticales para materiales educativos en lenguas indígenas y proyectos de documentación y atención a lenguas en riesgo de desaparición. Se ha involucrado en el desarrollo de material escrito en mixe y en la creación de lectores mixehablantes. Ha traducido textos literarios y especializados del inglés al castellano y del castellano al mixe, y mantiene una columna mensual en la edición digital de la revista Este País.

\section{LAURA POMERANTZ}

Es doctora y maestra en Historia del Arte, con honor, por la UNAM; licenciada en Historia del Arte (con honor) y en Literatura Hispanoamericana por la Universidad Hebrea de Jerusalén (Israel, 1985). Se especializa en Genocidio y Arte Contemporáneo, Arte Judío y del Holocausto. Incursionó en la curaduría independiente desde 2012, ha realizado exposiciones en Los Ángeles, México y Buenos Aires, es docente académica desde 1998, y ha participado en congresos y ha impartido conferencias en universidades de Estados Unidos, Canadá, México, Buenos Aires y Jerusalén. 


\section{SHEKOUFEH MOHAMMADI}

Doctora en Linguística Aplicada por la Universidad de Alicante. Su carrera profesional ha consistido en investigación, docencia y traducción. Actualmente es investigadora del Seminario de Hermenéutica del Instituto de Investigaciones Filológicas de la UNAM y como investigadora se ha dedicado a las aplicaciones de la semiótica a la literatura y las artes; la cultura y el arte persas son el centro de sus estudios. Sus líneas de investigación incluyen la hermenéutica literaria, la hermenéutica del símbolo y la hermenéutica cultural.

\section{AleXis DANIEl Rosim MiLlán}

Maestro en Teoría social, Filosofía de la Psicología y del Psicoanálisis por la Universidad Estadual de Campinas, doctorando en la Facultad de Filosofía y Letras de la UNAM. Actualmente, investiga algunos aspectos de la Filosofía de la liberación, Teología de la Misión Integral, el pensamiento teológico de Dieter Bonhoeffer y de Simone Weil. Por otro lado, estudia movimientos religiosos de resistencia civil como el movimiento puritano escocés, anabaptista y pietista alemanes, el movimiento moravo, la "Teología a caballo" de John Wesley y su visión de organización celular, el Movimiento Negro Norte-americano, las Comunidades Eclesiales de Base en América Latina, etc. Participa en dos colectivos evangélicos de reformulación de la justicia social - pacifistas, anti-neofascistas y anti-sistémicos - "Corazón Valiente" y "Búsqueda sin cesar".

\section{SERGio MÉndeZ MoISSEN}

Candidato a Doctor en Estudios Latinoamericanos por la UNAM. Ha impartido clases en el Centro de Estudios Sociológicos de la UNAM y en el departamento de Humanidades y Ciencias Sociales de la UACM. Realizó estancias de investigación en la EHESS en París, Francia y en el Centro Marinello en La Habana, Cuba. Ha publicado libros sobre el \#YoSoy132, sobre magonismo y luchas obreras. Su preocupación es recuperar las fuentes y tradiciones del pensamiento anticapitalista. 


\section{VERÓNICA VOLKOW}

Maestra y doctora en Literatura comparada y maestra en Historia del Arte. Ha sido becaria de Conaculta y actualmente es miembro del SNI. Es investigadora en el Seminario de Hermenéutica del Instituto de Investigaciones Filológicas de la UNAM. En 2004 recibió el Premio Pellicer por obra publicada y en 2005 el premio José Revueltas de Ensayo literario por El retrato de Jorge Cuesta. Entre sus libros pueden mencionarse: Los gladiadores demónicos (2009); Camino de vida: ensayos de poesía mexicana del siglo XX (2010); Miradas a la plástica mexicana del siglo XX (2010); De la demonización al análogo (2014); La mordedura de la risa: un estudio sobre la obra gráfica de Francisco Toledo (2015) y Dos cielos dos soles, imágenes de la totalidad del cosmos a finales del XVII novohispano (2014).

\section{PEDRo FAVARON}

Es comunero de Santa Clara de Yarinacocha, en la Amazonía peruana, en donde se hace cargo, junto a su esposa Astrith Gonzales, de la clínica de medicina tradicional Nishi Nete y su jardín etnobotánico. Cursó el Doctorado en Estudios Hispánicos de la Universidad de Montreal, comunicador social, periodista, investigador, ensayista y poeta. Ha colaborado en la construcción de talleres para que la comunidad de Santa Clara y las comunidades vecinas reaprendan los conocimientos y saberes necesarios para el óptimo desarrollo de artes que han sido practicados ancestralmente por este pueblo indígena (tejido, diseño, tallado, pintura, canto, cerámica, etcétera).

\section{RAFAEL MONDRAGÓN}

Doctor en Letras por la Universidad Nacional Autónoma de México, en cuya Facultad de Filosofía y Letras es profesor. Miembro del Sistema Nacional de Investigadores (Nivel I). Investigador del Seminario de Hermenéutica del Instituto de Investigaciones Filológicas y colaborador regular en círculos de lectura, talleres de educación popular y experiencias de trabajo cultural comunitario. Coordina el seminario "Una mesa para compartir objetos" que reúne a defensores de derechos humanos, investigadores y creadores dedicados a la sistematización de experien- 
cias de acción cultural que enfrentan la violencia en nuestro país. Es autor del libro Filosofía y narración. Escolio a tres textos del exilio argentino de Francisco Bilbao (1858-1864), y editor de Interpretatio. Revista de Hermenéutica. 